\title{
Following Hydrogen Cyanide in the Valencian Country (1907-1933): Risk, Accidents and Standards in Fumigation
}

\author{
Ximo Guillem-Llobat \\ López Piñero Interuniversity Institute, University of València \\ ximo.guillem@uv.es
}

Abstract: Pests had represented a major problem in agriculture for centuries, but the huge changes in the food chain around the late nineteenth century intensified their effects in a totally unprecedented way and many new chemical substances were introduced in the attempt to control them. In this paper I will focus on the implementation of hydrogen cyanide, a highly toxic pesticide which has not received particular consideration from researchers to date.

I shall analyse the introduction of this pesticide in the Valencian Country and focus on the attention given to the safety of workers and consumers. I aim to examine the role of the poison in its different uses and analyse the impact of each of them on safety regulations. Risks, accidents, and standards will be the main analytical categories I will use in my exploration of hydrogen cyanide and the safety regulations implemented in each context.

Keywords: cyanide, pesticides, accidents, public health, occupational health 


\section{Introduction}

In the 1890s, as modern societies grew aware of the importance of pest control, a number of toxicants were introduced in agriculture and in other settings. ${ }^{1}$ Pests had been a problem in agriculture for centuries, but the huge changes in the food chain already evident by the 1870s meant that the need for pest control was more urgent than ever before. ${ }^{2}$ Motivated by urbanization and industrialization and by the new opportunities offered by food preservation techniques, the food chain expanded at an unprecedented rate. However, the new intensive monoculture systems introduced as part of this process were more vulnerable to pests and their economic impact was particularly worrisome.

At that time, the physical methods of control which had been in use for centuries were widely considered to be insufficient and engineers intensified the search for new biological and chemical approaches. ${ }^{3}$ The chemical methods included the use of sulphates and oils, but also more toxic substances such as arsenical compounds and hydrogen cyanide. In this paper I shall focus on hydrogen cyanide and analyse its circulation and regulation in the Valencian Country. I am interested in establishing the extent to which this technology was actively appropriated in Valencia (as opposed to its passive reception) ${ }^{4}$ and in analysing the visibility or invisibility of the risk posed by the different uses of this toxicant when used in urban and in rural contexts.

The introduction of arsenical compounds as pesticides has already been analysed from similar perspectives by James Whorton and Nathalie Jas, and, in this issue, by José Ramón BertomeuSánchez. Nevertheless, little has been said about the use of hydrogen cyanide, a chemical which established itself as the main method of pest control in certain areas of the globe in the early twentieth century. Certainly, a comparison of the evolution in the use and regulation

\footnotetext{
${ }^{1}$ James C. Whorton, Before Silent Spring: Pesticides and public health in Pre-DDT America (Princeton, NJ: Princeton University Press, 1974); John H. Perkins, Insects, experts and the insecticide crisis (Berlin: Plenum Press, 1982); Nathalie Jas, "Public Health and Pesticide Regulation in France Before and After Silent Spring," History and Technology 23, no. 4 (2007): 369-88.

${ }^{2}$ John Burnett, Plenty and want: a social history of diet in England from 1815 to the present day (London: Scholar Press, 1979); Jack Goody, Cooking, Cuisine and Class: A Study in Comparative Sociology (Cambridge: Cambridge University Press, 1982); Jeffrey M. Pilcher, Food in World History (London and New York: Routledge, 2005).

${ }^{3}$ Adam M. Romero, "Commercializing chemical warfare: citrus, cyanide, and an endless war," Agriculture and Human Values 33, no. 1 (2016): 3-26.

${ }^{4}$ This paper builds on a historiography of science and technology "from the peripheries" as discussed in Kostas Gavroglu, et al., "Science and Technology in the European Periphery. Historiographical Reflections," History of Science 46, no. 152 (2008): 153-75; see also James Secord, "Knowledge in Transit," Isis 95, no. 4 (2004): 654-72, as well as the more critical perspectives of Fa-ti Fan, "The Global Turn in the History of Science," East Asian Science, Technology and Society: An International Journal 6, no. 2 (2012): 249-58.
} 
of arsenical pesticides and hydrogen cyanide would be very interesting, but I shall start by focusing on hydrogen cyanide and its notorious capacity to produce acute intoxications. ${ }^{5}$

In my analysis I shall build on theoretical frameworks such as those of the history of accidents ${ }^{6}$ and standards. ${ }^{7}$ I will also draw on my previous work with José Ramón Bertomeu-Sánchez dealing with poisons as complex socio-material phenomena. ${ }^{8}$ Without ignoring their material aspects, we have focused on the huge range of social uses and cultural meanings associated with poisons. These uses and meanings are contingent and changeable through time and space; for instance, a specific poison such as arsenic could be used either as a criminal tool to perform murder, or as a therapeutic tool to cure patients. ${ }^{9}$

Particular poisons, then, have caused terror in some contexts but have been regarded as harmless or even beneficial in other places or moments in history. And even if a certain substance has acquired a generally negative value, perceptions of it vary widely depending on whether it is considered as an environmental toxicant, an occupational hazard, an adulterant or a criminal poison. The uses, meanings and regulations have not always circulated between these contexts as smoothly as one might have imagined; in addition, historians have tended to deal with them as isolated (parcelled up) entities. ${ }^{10}$

\footnotetext{
${ }^{5}$ In his manual on the use of hydrogen cyanide in disinfection (published ca. 1930) the Spanish physician Vicente Cebrián Gimeno stated that this substance was the most active, rapid, and fatal poison ever known. He referred to the death of the chemist from Vienna, Scharinger, two hours after pouring two drops of hydrogen cyanide on his arm. He then gave numerical data to show its high toxicity. For instance, he stated that a dose of 50-70 mg would kill a man and that its vapours were extremely toxic, although for a while one could breathe in an atmosphere of up to $0.06 \mathrm{~g} / \mathrm{m}^{3}$. Cebrián Gimeno estimated a maximum concentration limit for the human organism of 0.024 percent. This meant that an exposure of a few seconds to the hydrogen cyanide vapours generated in fumigations would be lethal and therefore there was no need for any great debate on the acceptable limits. For further details see: Vicente Cebrián Gimeno, Manual de la desinfección por el ácido cianhídrico (a bordo y en tierra) (Madrid: Talleres Voluntad, ca. 1930).

${ }^{6}$ Roger Cooter and Bill Luckin, eds., Accidents in History: Injuries, Fatalities and Social Relations (Amsterdam: Rodopi, 1997); Tom Crook and Mike Esbester, eds., Governing risks in modern Britain: danger, safety and accidents, c. 1800-2000 (London: Palgrave Macmillan, 2016).

${ }^{7}$ Martha Lampland and Susan Leigh Star, eds., Standards and their stories. How quantifying, classifying, and formalizing practices shape everyday life (Ithaca \& London: Cornell University Press, 2009); Olga Kuchinskaya, "Twice invisible: Formal representations of radiation danger," Social Studies of Science 43, no. 1 (2013): 78-96; Kevin C. Elliot, "Selective ignorance in environmental research," in Routledge International Handbook of Ignorance Studies, eds. Matthias Gross and Linsey McGoey, 165-73 (London and New York: Routledge, 2015).

${ }^{8}$ José Ramón Bertomeu-Sánchez and Ximo Guillem-Llobat, "Following Poisons in Society and Culture (1800-2000): A Review of Current Literature," Actes d'Història de la Ciència i la Tècnica 9 (2016): 9-36.

9 David Arnold, Toxic Histories: Poison and Pollution in Modern India (Cambridge: Cambridge University Press, 2016).

${ }^{10}$ Bertomeu-Sánchez and Guillem-Llobat, "Following Poisons."
} 
In developing this framework, José Ramón Bertomeu-Sánchez and I set out to abandon this segmented approach to the history of toxicants or poisons. In order to do so, we have tried to trace the main historiographical approaches to the study of these substances, and then to identify potential points of convergence. These approaches have usually included the history of crime, the history of food, the history of occupational and public health, and environmental history. But, as I shall state, when dealing with a specific toxicant such as hydrogen cyanide not all these approaches will be equally productive. I shall therefore resituate the disciplinary divide we shall be crossing when following this specific toxicant through space and time.

As for the points of convergence, in this paper I shall focus on risk, accidents, and standards. Risk has been an important category in historiography since the 1980s, when Ulrich Beck published his work Risikogesellschaft. Recently, Beck's concept of risk has been increasingly criticized for concealing class conflicts, for its periodization, and so on. Nonetheless, risk remains a relevant category for analysing cases such as the one considered in this paper. According to Tom Crook and Mike Esbester, the studies on risk following Beck's book have also drawn attention to the importance of accidents, another category which will have a special place in this paper. ${ }^{11}$ The need for a history of accidents was highlighted by Roger Cooter and Bill Luckin in 1997 in their book Accidents in History: Injuries, Fatalities and Social Relations, although the scholarly world seemed reluctant to accept this category. Cooter and Luckin provided several possible explanations for this unwillingness. The first was the definition of accidents as contingent and insignificant, the result of carelessness, events that are usually preventable; and second, the insistence on probability and statistics which Beck's work seemed to require served to make accidents invisible. As Crook and Esbester show in their book, this conception has recently changed and the avenues opened up by Cooter and Luckin are receiving increasing attention from researchers. ${ }^{12}$

The third point of convergence will be standards. I will briefly consider the politics of standards and formal representations to which authors such as Susan Leigh Star, Olga Kuchinskaya and others have referred in their respective works. ${ }^{13}$ These authors have insisted on the ubiquity of standards in our societies, and have stressed how these standards are established in specific contexts and despite being initially challenged, at some point they become naturalized and therefore black boxed. The significance of this process can be understood by going back to Alfred Whitehead's fallacy of misplaced concreteness. ${ }^{14}$ Popularized in the 1920s, this concept established that scientists and philosophers "suffer from a tendency to assume that their

\footnotetext{
${ }^{11}$ Crook and Esbester, Governing risks.

${ }^{12}$ Cooter and Luckin, Accidents in History; Crook and Esbester, Governing risks.

${ }^{13}$ Lampland and Leigh Star, Standards and their stories; Kuchinskaya, “Twice invisible;" Elliot, "Selective ignorance."

${ }^{14}$ Alfred N. Whitehead, Science and the Modern World (New York: Macmillan, 1925).
} 
abstractions of a phenomenon adequately capture all its nuances." ${ }^{15}$ Authors such as Kevin C. Elliot have stressed that this concept can lead to selective ignorance; ${ }^{16}$ by focusing on the establishment of a standard definition of occupational accident this paper shows how this tendency can contribute to making risk invisible.

\section{Cyanide spraying: from California to the Valencian Country}

The method of cyanide fumigation for pest control was first developed in California in the fall of $1886 .{ }^{17}$ Citrus production was expanding rapidly in this area at the time, and as it spread, scientists began to be aware of the effect of pests. In the 1880s a group of researchers led by the entomologist Daniel William Coquillett engaged in the search for an effective treatment for the Icerya purchasi pest, as well as for other scale insect pests, and decided that cyanide fumigation was the best solution. ${ }^{18}$ In the following years, thanks to the work of the scientists Russell Sage Woglum, Leland Ossian Howard and Henry J. Quayle, the method became one of the most important in citrus pest control. ${ }^{19}$ The influence of these researchers soon spread from the United States to other parts of the globe.

In 1907 the "red scale" became a serious pest in the Valencian Country and in Andalusia. That same year, a number of cyanide fumigation tests were carried out in these areas. ${ }^{20}$ This prompt reaction to the pest was obviously due to the economic relevance of the citrus crop, which was in clear expansion at the time. For decades, Spain would dominate international orange production and the Valencian Country would account for over 80 percent of the total Spanish output. ${ }^{21}$ Between 1930 and 1935, oranges accounted for 17.8 percent of the value of all Spain's exports. ${ }^{22}$

In his Manual práctico para el cultivo del naranjo published in 1905 the Valencian engineer Antonio Maylin had already reported that the main agricultural research station in the region, then called the Experimental Farm Institute of Agriculture of Valencia (Granja Instituto de Agricultura de Valencia), had carried out several experiments with cyanide fumigation in order

\footnotetext{
15 Elliot, "Selective ignorance," 166.

${ }^{16}$ Ibid.

${ }^{17}$ Romero, "Commercializing chemical warfare."

${ }^{18}$ Rafael Font de Mora, Nuevo Método de Fumigación por el Líquido Ácido Cianhídrico. Su aplicación al naranjal y efectos sobre las plagas (València: Imprenta La Semana Gráfica, 1932).

${ }^{19}$ Romero, "Commercializing chemical warfare."

${ }^{20}$ Font de Mora, Nuevo Método de Fumigación.

${ }^{21}$ Samuel Garrido, "Oranges or 'Lemons'? Family Farming and Product Quality in the Spanish Orange Industry, 1870-1960,” Agricultural History 84, no. 2 (2010): 224-43.

22 Samuel Garrido, "Plenty of trust, not much cooperation: social capital and collective action in early twentieth century eastern Spain," European Review of Economic History 18, no. 4 (2014): 413-432.
} 
to test its efficiency in fighting "serpeta" and "poll roig" (red scale). ${ }^{23}$ However, none of these experiments seem to have been particularly successful; engineers and agricultural institutions did not accept the treatment immediately, but instead first tested a good number of less hazardous insecticides. ${ }^{24}$ The potential harm caused by hydrogen cyanide on workers and on the trees had been noted by Maylin in his above-mentioned publication, ${ }^{25}$ but in concluding that the potential benefits of cyanide fumigation were limited, he placed more emphasis on the high cost of the treatment.

Leopoldo Salas y Amat, the engineer in charge of the Agricultural Section in Malaga, played a key role in the introduction of cyanide fumigation in the Iberian Peninsula. Other important protagonists were Enrique Trénor Montesinos, Conde de Montornés, and Leandro Navarro, an engineer and director of the Madrid Plant Pathology Station (Estación de Patología Vegetal de Madrid). All three helped in the appropriation of the treatment developed in California. In this process, reports and publications by American entomologists were consulted and translated, experts such as Howard and Woglum were contacted, and original research was carried out in order to adapt the method to the particular conditions of Malaga, Valencia and elsewhere in Spain.

The role of Leandro Navarro was especially important in the second stage, when this pest control method was adapted for application to olive production. ${ }^{26}$ In Valencia, the Conde Montornés was an important figure. Born in 1861, the count was a Valencian politician, agricultural producer and lobbyist who had studied science at the University of Valencia and later received his doctorate from the Central University of Madrid. After research stays in England and Belgium studying agriculture, he went back to Valencia where he introduced a number of novel practices into his own orchards. He held important posts in local institutions, being appointed Royal Commissioner of the Ministry of Development (Comisario Regio de Fomento) and head of the Valencian Provincial Council of Development (Consejo Provincial de Fomento de València) and was also a member of parliament. He was a member of the Conservative party but served in parliament as an independent representative for the districts of Xiva and Valencia. He organized several international meetings on agriculture and was the Spanish representative

\footnotetext{
${ }^{23}$ Antonio Maylin, Manual práctico para el cultivo del naranjo (València: Tipografia Moderna, 1905). Serpeta was identified with several species including Mytilaspis citricola and Mytilaspis gloverii. The poll roig was identified as Chrysomphalus dictyospermi (red scale).

${ }^{24}$ Spanish Royal Order of 19 September 1910; Maylin, Manual práctico.

${ }_{25}$ Maylin, Manual práctico.

${ }^{26}$ Leandro Navarro Pérez, Nuevas aplicaciones del procedimiento de fumigación con el ácido cianhidrico a la extinción de una plaga de los olivos (Madrid: Blass SA, 1924); Leandro Navarro Pérez, Conferencia sobre el Arañuelo de los olivos (Madrid: Tomás Blasco, 1913).
} 
at the International Commission of Agriculture in Paris and the International Institute of Agriculture in Rome. ${ }^{27}$

The Conde de Montornés's key role in the appropriation of cyanide fumigation was acknowledged by many of his contemporaries. He translated a report on the practice by the US Ministry of Agriculture, presented the work at the Agricultural Chamber of Valencia (Cámara Agricola de València), applied for funding from the Civil Governor in Valencia and then from the Spanish government to arrange a visit by one of the American entomologists working on these fumigations, ${ }^{28}$ and corresponded with a number of agricultural experts and institutional representatives in the United States. ${ }^{29} \mathrm{He}$ enjoyed the support of several institutions in Valencia, which wrote a joint letter to the Ministry of Development (Ministerio de Fomento) requesting the funding needed to introduce cyanide fumigation in the region. ${ }^{30}$ And when this support was received, the Conde organized the visit of the American entomologist Woglum and acted as his host.

In August 1910, en route to India, Woglum stopped off in the Iberian Peninsula at the request of L.O. Howard, chief of the US Bureau of Entomology, and led or supervised several experiments with cyanide fumigation in Malaga and the Valencian Country. ${ }^{31}$ In Malaga, the engineer Salas y Amat had already prepared a special team to carry out cyanide fumigations. On his visit, Woglum was able to supervise and approve their work and concluded that there was no need to engage an American specialist to prepare the Spanish workers for several months, as Salas y Amat had already demonstrated his proficiency for carrying out this role. ${ }^{32}$

Woglum's visit was neither the first by a US agricultural scientist related to cyanide fumigation, nor the last. In May 1910 Howard had already visited Madrid and met the main representatives of the Spanish agricultural services. ${ }^{33}$ Quayle, from the University of California, visited Valencia in 1923 to demonstrate the new methods of fumigation that had been introduced in California. ${ }^{34}$ These visits were very well received and were reported not

\footnotetext{
27 “Notas necrológicas. El conde de Montornés," Agricultura. Revista Agropecuaria, January 1929, 27.

${ }^{28}$ See for instance: "En la Cámara Agrícola. Conferencia del señor conde de Montornés," Las Provincias: diario de Valencia, March 21, 1910, 1.

29 Conde de Montornés, Ampliación al folleto sobre las fumigaciones con el ácido cianhidrico en los naranjales de California (València: Imp. de Antonio López y C $\left.{ }^{a}, 1910\right)$.

30 "Contra el poll roig," El Pueblo: diario republicano de Valencia, April 29, 1910, 2.

${ }^{31}$ Federíco Gómez Clemente and Francisco G. Regueral Bailly, Estación de Patología Vegetal de Levante. Instrucciones que deben observarse en los trabajos de fumigación con el ácido cianhidrico (València: Imprenta de Hijo de F. Vives Mora, 1934).

${ }^{32}$ Spanish Royal Order of 19 September 1910.

${ }^{33}$ Ibid.

${ }^{34}$ Font de Mora, Nuevo Método de Fumigación.
} 
just in agricultural publications ${ }^{35}$ and by the Spanish and US agricultural services, ${ }^{36}$ but also in broadsheet newspapers (in particular, the Valencia papers Las Provincias, El Pueblo and La Correspondencia de Valencia). On occasions, the reports and news stories gave such prominence to these visits that this process of technological transfer might be seen as involving a merely passive reception of the method developed in California; however, the protagonism of Salas y Amat (though rarely acknowledged in the news reports) ${ }^{37}$ and the enthusiastic participation of Valencian engineers at a later date indicate that the appropriation of these new methodologies was clearly an active process.

The introduction of the new technology at local level benefited from these visits in multiple ways. The exchange of knowledge and experience was essential, but the visits also went a long way to raising the profile of the ongoing research. Their impact became obvious with the publication of the Royal Order of 19 September 1910, which set up a service to coordinate the introduction of cyanide fumigation in the fight against the red scale pest. In the main text of the regulation and in the reports published in a number of newspapers, this order was presented as the direct consequence of Woglum's visit. ${ }^{38}$

The events of 1910 mentioned above were very important for the appropriation of cyanide fumigation, but they were not in fact the first references to the procedure in the Iberian Peninsula. In 1901 and 1904 several articles on fumigation had been published in the nonspecialist press, ${ }^{39}$ and in 1905 an interesting experiment in Mallorca might also have constituted a starting point for the appropriation of this procedure. ${ }^{40}$ In June 1905 a special scientific commission from the Laboratory Arago in Banyuls-sur-Mer in France visited the island, on a trip mainly concerned with marine biology. During their visit they were taken to the town of Sóller, where the local citrus production was suffering from a new plant disease. The French scientists identified its cause as the red scale pest. Cyanide fumigation was then suggested as a possible solution by French experts, but this did not have the impact it would later have in 1910, and no special service was set up. The limited scale of the plague, and the lack of a

35 "La campaña contra el 'poll roig' y Mr Woglum," El Progreso Agrícola y Pecuario, September 7, 1910, 514-15.

${ }^{36}$ Leland O. Howard, A History of Applied Entomology: Somewhat Anecdotal (City of Washington: The Smithsonian Institution, 1930).

37 The lack of recognition of the work done by the local engineers was already criticized in articles such as "La campaña contra el 'poll roig' y Mr Woglum."

38 See for instance: "Epílogo de una campaña," Las Provicias: diario de Valencia, October 7, 1910, 4.

39 "Fumigación de los frutales en California," Soller: semanario independiente, November 30, 1901, 1. The same article was published several days later in the Diario de Tenerife and the Diario Palentino. In 1904, articles on cyanide fumigation appeared in La Región: periódico bisemanal, La Correspondencia de Alicante: diario noticiero and La Huerta de Gandia.

40 “Qué lección!,” El liberal: órgano democrático de la isla de Menorca, June 27, 1905, 3. 
dedicated, committed figure such as the Conde de Montornés, may have been the reasons for the failure of the procedure to establish itself in Mallorca.

Over this period, dozens of newspaper articles and several scientific reports discussed the possibilities and the limits of cyanide fumigation in fighting the red scale and other pests. As noted, certain publications made brief references to the dangers of cyanide fumigation, but in most cases the risks were ignored or dismissed. In 1904, for instance, La Región reported that cyanide fumigations were safer than those using sulphurous acid; cyanide, the newspaper claimed, was more effective against pests and had a lesser impact on the plant. The article went on to state that although no one could deny the toxicity of hydrogen cyanide, it would not harm farm workers in any way provided the fumigation observed the correct method. ${ }^{41}$ In 1910, the Revista de Gandia claimed that the method of fumigation developed in California was the best for fighting pests "without danger." ${ }^{\prime 2}$ This systematic denial of the risks involved in this procedure predominated for years, even when, in the 1920s, the first reports of fatal cases of intoxication began to appear in the press.

While little was said about the potential health effects on workers, the economic cost of the treatment did raise concern. In the special section in Agricultura devoted to answering questions sent in by farmers, we find a number of replies by the engineers in charge of the section urging them to look for alternative methods, because of the high costs of fumigation. ${ }^{43}$ When farmers were unwilling or unable to join together with their neighbours to carry out the cyanide fumigations, engineers recommended other treatments that were less effective but cheaper; when farmers did join forces and fumigated together, the engineers were fulsome in their praise. ${ }^{44}$

\section{Legislation on pest control}

The projects devised by the engineers, ${ }^{45}$ entomologists, and other agricultural experts that

\footnotetext{
41 "Las fumigaciones de gases en el tratamiento de los pulgones y cochinillas de los frutales," La Región: periodico bisemanal, April 15, 1904, 1.

42 "Conferencia importante," Revista de Gandia, March 26, 1910, 3.

43 See for instance: Miguel Benlloch, "Consulta núm. 57. Cochinillas del olivo," Agricultura. Revista agropecuaria, December 1929, 765-66.

44 "La semana agrícola. La segunda conferencia. Plagas del campo," El Eco Toledano: Diario defensor de los intereses morales y materiales de Toledo y su provincia, October 11, 1913, 2.

45 In Spain, pest control in agriculture was mainly developed by agronomists. Entomologists also participated, but they had a secondary role (in clear contrast to their counterparts abroad - most of the American experts in fumigation with whom the Spanish engineers dealt were entomologists). For more information on the role of Spanish agronomists in pest control and other agricultural policies see: Juan Pan-Montojo, Apostolado, profesión y tecnología. Una historia de los ingenieros agrónomos en España (Madrid: Asociación Nacional de Ingenieros Agrónomos, 2005).
} 
we have mentioned were essential for the effective introduction of cyanide fumigations in the Iberian fields. However, the process also required a major change in the legislation on pest control. Before the turn of the century only two general regulations had been passed regarding pests: one regarding phylloxera in 1878 , and one referring to locusts in $1879 .{ }^{46}$ The first general law on pest control was passed in $1908 .{ }^{47}$ Although the two pests mentioned above featured prominently in this new legislation, it also included a general definition of "pest" and the first attempt to establish the institutional framework able to fight pests of all kinds; it covered the procedure for funding pest control, and established responsibilities. The law was completed and slightly modified with further legislation such as the Royal Decree of 21 October 1910, but for decades it provided the general legal framework for pest control.

The legal framework of 1908 spurred the introduction of cyanide fumigation in the following years. As noted above, engineers had been testing this treatment since 1907, but they were also interested in additional or alternative methods of chemical control. The Royal Order of 19 July 1910 promoted an international competition for pest control in Valencia, and the jury's final verdict was issued in 1912: finally, however, the first prize was not awarded in a competition in which cyanide fumigation was not one of the candidates.

At this time, legislation was passed to promote specifically the use of cyanide fumigation. The Royal Order passed on 19 September 1910 gave a detailed account of the history of the introduction of the practice in Spain. It stressed the importance of the legal framework established in 1908 in terms of funding and the safety requirements, and defined ways in which the American method could be adapted and training provided for the workers. The Royal Order of 17 June 1911 also insisted that cyanide fumigations should be carried out in the regions suffering from the above-mentioned pests. Both orders assigned the coordinating activities to Salas y Amat, who was to carry them out within the framework established by the law of 1908.

By the 1920s, when the chemical fight against pests was already underway, the option of biological control was also considered. ${ }^{48}$ The poor results of cyanide fumigation in fighting the Icerya purchasi pest contrasted starkly with the results obtained with the introduction of this insect's predator, the beetle Rodolia cardinalis. This strategy was particularly popular in areas like Valencia, and was accompanied by the publication of special rules and notices in the official state gazette. ${ }^{49}$

\footnotetext{
46 Acts of 30 July 1878 and of 10 January 1879.

47 Act of 23 May 1908.

${ }^{48}$ For more information on biological pest control in the Valencian Country see, for instance: Jesús Català and Ximo Guillem-Llobat, "Control de plagas y desarrollo institucional en la estación de Patología Vegetal de Burjassot (València),” Asclepio 58, no. 1 (2006): 249-80.

49 Dirección General de Agricultura y Montes, Notice of 9 November 1922.
} 
Nonetheless, cyanide fumigation was the focus of most of the efforts to fight pests in some specific areas, such as the Valencian Country, and in specific crops such as oranges and olives. This emphasis was obvious in legislation passed in the 1920s and 1930s, which either dealt with investments in specific equipment for cyanide fumigation, ${ }^{50}$ or promoted these fumigation methods in particular crops. ${ }^{51}$

Moreover, if we look at the introduction of fumigation not just in terms of its effectiveness against pests but also in terms of the exposure of society to serious risks, we should also explore how these risks were regulated. The presence of residues in the fruit did not receive any special attention either in the Valencian Country or in Spain: no serious discussions of this hazard have been identified, even though specific regulations introduced in the 1930s, such as the Estatuto del vino, established threshold values for hydrogen cyanide in products such as liquors; in this specific case of $40 \mathrm{mg} / \mathrm{l}^{52}$ And even at international level the issue does not seem to have acquired any special relevance until the 1930s. A couple of publications, which appeared in 1936 and 1941 respectively, dealt with the absorption and retention of hydrogen cyanide by fruit after fumigation. ${ }^{53}$ However, the issues raised in these studies were largely ignored in the attempts to regulate the safety of fumigations during the period.

The other major risk which might have been regulated was the risk to workers associated with potential accidents occurring in fumigating. The regulation of occupational accidents experienced changes at the turn of the century: on 30 January 1900 the Work Accident Act (Ley de Accidentes de Trabajo) was passed, and on 28 July 1900 a Royal Decree established the basis for its application. This move could have established the legal framework needed to regulate fumigations and avoid undesired accidents; however, the way in which accidents were defined and the fact that the law dealt specifically with commercial and industrial activities, and not with agriculture, were significant drawbacks. The standard definition of accident established by the law focused on physical damage rather than on acute intoxication, and still less on chronic poisoning. Intoxication did not qualify for compensation and thus became invisible; the lack of consideration of accidents in agriculture until the passing of several laws in the 1930s also heightened this invisibilization.

This delay in regulating agricultural labour was due in part to the absence of strong unions, because the citrus fruit sector had a high percentage of small producers which used family

\footnotetext{
50 Spanish Order of 15 June 1931.

51 Spanish Decree of 16 June 1932.

52 Estatuto del vino y los alcoholes, Spanish Decree of 8 September 1932.

53 E.T. Bartholomew and E.C. Raby, "The recovery of hydrocyanic acid from fumigated citrus leaves," Journal of biological chemistry 113, no. 3 (1936): 655-60; E.T. Bartholomew, W.B Sinclair and D.L. Lindgren, "Factors affecting the absorption and retention of hydrocyanic acid by citrus leaves and fruits," Journal of economic entomology 34 (1941): 815-21.
} 
labour rather than hired hands. ${ }^{54}$ What is more, the lack of well-trained, organized experts meant that the accepted definition of work accident went unchallenged. Historians such as Alfredo Menéndez and Estaban Rodríguez-Ocaña note that Spanish occupational medicine was basically non-existent until the passing of the Compensation for Work Accidents Act of January 1900, and later steps such as the foundation of the Spanish Society of Occupational Medicine in 1934.55

\section{The scale of cyanide fumigation in the Valencian Country}

The Royal Order of September 1910, and others such as that of June 1911, established that the fumigations would be introduced under the supervision of the engineer Salas y Amat, from Malaga. ${ }^{56}$ Salas y Amat was to coordinate a group of five engineers from different provinces who would decide where, when, and how to carry out these fumigations However, at some point, this initial commission would give way to other organizations and, in the following years, the area of Valencia emerged as a key player in its regulation and coordination. We still do not know the details of this transition, but it is worth noting that Clemente Cerdá, from Valencia, was among the initial group of engineers coordinated by Salas y Amat. In these early stages, Cerdá led an official squad that would carry out fumigations in several municipalities in the province of Valencia and started to coordinate special courses for fumigation foremen at the Experimental Farm Institute of Agriculture of Valencia, now called the Practical Farm School of Burjassot (Granja Escola Práctica de Burjassot). ${ }^{57}$ The success of Cerdâs work seems to have established Valencia as the only official centre capable of producing qualified foremen (in order to carry out fumigations, the squads needed at least one such figure). This exclusive training role played by the experimental farm of Burjassot was noted in 1934 by the Valencian engineer Federico Gómez Clemente, and was acknowledged by the engineer Silverio Planes as late as $1954 . .^{58}$

The first course taught at the experimental farm of Burjassot was held in 1912 and from then on the courses became an annual event. In previous years engineers like Cerdà had

\footnotetext{
54 Samuel Garrido, "Oranges or 'Lemons'?”

55 Alfredo Menéndez-Navarro and Esteban Rodríguez-Ocaña, "From 'accident medicine' to 'factory medicine': Spanish occupational medicine in the twentieth century," in Origins of Occupational Health Associations in the World, eds. A. Grieco; T. Carter and S. Iavicoli, 207-16 (Amsterdam: Elsevier Science, 2003); Esteban Rodríguez-Ocaña and Alfredo Menéndez-Navarro, "Salud, trabajo y medicina en la España de la legislación social, 1900-1939," Archivos de Prevención de Riesgos Laborales 9, no. 2 (2006): 81-88.

56 Spanish Royal Order of 19 September 1910 and Spanish Royal Order of 17 June 1911.

57 Also known by other names during the period, such as the Granja Escuela Experimental.

58 Gómez Clemente and Regueral Bailly, Estación de Patología Vegetal de Levante. Instrucciones; Silverio Planes, Plagas del Campo (Madrid: Ministerio de Agricultura, 1954).
} 
coordinated special demonstrations of cyanide fumigation for farmers, but in August 1911, in an article published in the newspaper Las Provincias, the engineer Maylin wrote of the need to implement special courses. ${ }^{59}$ These courses, which prepared participants to obtain the licence, were first planned to last 10 to 12 days and were finally extended up to 14 days. As entry requirements, participants had to know how to read and write and have basic arithmetic skills. Once accepted, they received the course for free and were also paid a salary for each day of the course they attended. The contents of the course evolved over the years. From the beginning, it was intended to produce the trained agricultural workers needed to staff the fumigation squads in the fight against the red scale pest and other pests, affecting mainly orange and olive crops. Cyanide fumigation was thus absolutely central to the courses and the practical demonstrations, and in the manual supplied to the students on the first day entitled Instructions that must be followed in cyanide fumigations (Instrucciones que deben observarse en los trabajos de fumigación con el ácido cianhidrico). The book was first published in 1912 and was reprinted on several occasions in the following years.

Other pesticide treatments were also introduced in these courses. For instance, in the course outline for 1938, after a general introduction to pests and plant diseases, we find several instructions on how to prepare and use treatments such as the Bordeaux mixture and lead arsenate. However, more than half of the course was still dedicated to cyanide fumigation in its different forms. ${ }^{60}$

These courses were made possible by (and clearly benefited from) the evolution in the institutional framework for pest control in Valencia. In 1892 the experimental farm of Valencia was relocated in the neighbouring municipality of Burjassot, where it would stay until the 1970 s. ${ }^{61}$ And in 1908, after the passing of the law on pests, the government decided to create a centre for pest control linked to this experimental farm. At that moment there was only one centre of this kind, in Madrid, linked to the Institute of Agriculture Alfonso XII (Instituto Agrícola Alfonso XII). The importance of Valencian agricultural exports and the impact that the red scale was having on orange production were in all probability the reasons for the establishment of this second centre in Valencia. ${ }^{62}$ In 1909, the Burjassot Plant Pathology Station (Estació de Patología Vegetal de Burjassot) was created and although it was

\footnotetext{
59 Antonio Maylin, "La fumigación de los naranjos," Las Provincias: diario de Valencia, August 5, 1911, 1.

60 "Programa para la enseñanza de capataces fumigadores. Cursillo de Junio de 1938," caixa 17, any 1938-9, Estación de fitopatología agrícola de Levante, Arxiu Històric de la Universitat de València (hereafter cited as Estación de fitopatología, AHUV).

${ }^{61}$ Salvador Zaragoza Adriaensens, Origen y actividades del Instituto Valenciano de Investigaciones Agrarias 1868-2000 (València: IVIA, 2011), http: //www.ivia.gva.es/libro-salvador-zaragoza (accessed April 5, 2019); Català and Guillem-Llobat, "Control de plagas."

${ }^{62}$ Zaragoza Adriaensens, Orígen y actividades del Instituto Valenciano de Investigaciones Agrarias.
} 
never independent from the experimental farm of Burjassot, it provided an ideal context for the development of the courses and the research needed in order to implement cyanide fumigation. On 20 June 1924 a new Royal Order aimed at reorganizing the institutional framework of Spanish agricultural services was passed, which provided for the creation of several plant pathology stations, among them the one in Valencia. Not all of these stations finally came into being, but the one in Valencia was particularly active. When the experimental farm of Burjassot (with which the station shared a building) closed down in 1931 and the Orange Research Station of Valencia (Estació Tarongera de Llevant), which focused on orange production, was created in its place, the institutional context was even more propitious for the practice of cyanide fumigation.

The beginning of the Spanish Civil War in 1936 complicated the situation. The difficulties in securing the supply of the reagents needed for fumigation meant that alternative and complementary treatments were applied in its place, ${ }^{63}$ although cyanide fumigation continued to be used for several decades. Interestingly, the control of these fumigations could still be used for social and political purposes after the war. For instance, in 1941, with the advent of the new fascist regime, all previous official licences were revoked and fumigation foreman were obliged to take a new training course. No great changes in the course content were introduced, but applicants now had to present a certificate of good behaviour signed by the municipal government or the fascist organization Traditionalist Spanish Phalanx and of the Councils of the National Syndicalist Offensive (Falange Española Tradicionalista y de las Juntas de Ofensiva Nacional Sindicalista). ${ }^{64}$

The expansion of cyanide fumigation was not due solely to the organization of the courses mentioned above. The courses played a vital role and were very successful, and by 1940 the centre had granted roughly 1350 fumigator foreman licences; ${ }^{65}$ but at the same time, new methods of fumigation were tested and introduced in the field and the doses used were revised. ${ }^{66}$ So, as I suggested above, it seems fair to speak of an active appropriation of the method first developed in California.

The growth of the practice can be measured in very different ways. In early 1911 there was one official squad operating in the province of Valencia, and maybe a few private ones (we

63 "Informe sobre el estado fitosanitario naranjero 1939," caixa 1, Subcarpeta E, Estación de fitopatología, AHUV.

${ }^{64}$ Caixa 17, any 1938-9, Estación de fitopatología, AHUV.

65 "Relación de los capataces fumigadores que figuran inscritos en el libro de la Estación de Fitopatología Agrícola de Burjasot (Valencia),” Estación de fitopatología, AHUV.

${ }^{66}$ Federico Gómez Clemente and Francisco G. Regueral, Rectificación de las tablas actualmente utilizadas en la fumigación cianhidrica de los agrios en España (València: Estación de Fitolpatología Agrícola de Burjasot, 1939). 
know that the Grima-Berdín Society organized six squads), ${ }^{67}$ but by 1928 there were more than $200,{ }^{68}$ and in 1933 the engineer Silverio Planes stated that the figure had risen above 400 crews; every year 800 tonnes of sodium cyanide and 10 tonnes of calcium cyanide were imported to Valencia, while the province also produced 300 tonnes of liquid hydrogen cyanide. $^{69}$ This increase had already been predicted by Gómez Clemente, who, in 1928, urged that the training should be stepped up in order to produce enough workers to fumigate all the fields every two or three years. ${ }^{70}$ The fumigation was mainly to be applied in orange and olive trees, but over the period we also find projects for its use in other crops such as hazelnuts. ${ }^{71}$

Private initiative was particularly important in the expansion of cyanide fumigation. In the city of Valencia, the company Casa Grima was created in the second decade of the twentieth century. In 1911 we find the first references in the press to the Grima-Berdín Society, which owned a factory for the production of pesticides and an agricultural office that provided information on pests. ${ }^{72}$ In the following year the company appears to have split and the newspapers refer either to J. Berdín y $\mathrm{C}^{\mathrm{a}}$ or to Casa Grima y Hermanos, but the new firms continued to grow and we find a large number of articles referring to them, as well as advertisements, published in the press in the following years.

Some of the newspaper articles on these firms were, as explicitly stated, the result of invitations made by the companies to local journalists, in an attempt to demonstrate the efficiency of the pesticides that they had developed or commercialized, ${ }^{73}$ or to restore their reputations after cases of intoxication. For instance, Casa Grima canvassed journalists very effectively and persuaded them to publicize the firm's rapid response after a number of cooks were intoxicated due to the fumigation carried out by one of its squads. The press gave a glowing report of the company's reaction and wrote that the cooks had survived

\footnotetext{
${ }^{67}$ L. León Durán, "Las fumigaciones con el ácido cianhídrico," Las Provincias: diario de Valencia, December 22, 1911, 1 .

68 "Plan para la enseñanza teórico práctica de capataces fumigadores en la Estación de Fitopatología Agrícola de Valencia [Informe del Ingeniero Director de la Estación de Patología Vegetal de Burjasot, 6 de junio de 1928]," Estación de fitopatología, AHUV.

69 Silverio Planes Garcia, "Las plagas de los frutales en Levante," Agricultura. Revista Agropecuaria, March 1933, 151-55.

70 "Plan para la enseñanza teórico práctica de capataces fumigadores en la Estación de Fitopatología Agrícola de Valencia [Informe del Ingeniero Director de la Estación de Patología Vegetal de Burjasot, 6 de junio de 1928],” Estación de fitopatología, AHUV.

71 “Consejo Provincial de Fomento de Tarragona," El Restaurador: diario de propaganda católico-socialy de avisos, November 21, 1911, 1.

${ }^{72}$ León Durán, "Las fumigaciones con el ácido cianhídrico."

73 "Nuevo centro para la clase agraria," Revista de Gandia, August 10, 1912, 1.
} 
"thanks to the professional action of the company's technical staff." 74 These two firms, then, cultivated their presence in the media to great effect.

These firms were particularly active in the province of Valencia, and there are reports of their presence elsewhere in the Iberian Peninsula. ${ }^{75}$ In fact, a documentary film made in the 1930s shows that Casa Grima also had international concerns, as it marketed its treatments in countries such as Argentina and Uruguay. ${ }^{76}$

The Grima-Berdín Society developed several pesticides which were well received by the engineers from the experimental farm of Burjassot and the firm was also heavily involved in the introduction of cyanide fumigations. As early as January 1912, the newspapers reported on the successful activities of several squads run by the firm under the supervision of the engineer Clemente Cerdá. ${ }^{77}$ After the split, Casa Grima appears to have played a more active role in cyanide fumigation.

Another major firm involved in cyanide fumigation was Fumigadores Químicos S.A. This company was created in Valencia by the US firm American Cyanamid, and produced reagents for cyanide fumigation such as cyanogas. Occasionally the press also mentioned other smaller companies in connection with cyanide fumigation, such as Casa J. Fayos. ${ }^{78}$ This rich market of firms of all sizes in fumigations sometimes sparked controversy: Casa Grima, for instance, complained that their rivals were charging for treatments that they did not carry out, and lobbied for the introduction of regulation through an active media campaign. ${ }^{79}$ Interestingly, in this campaign, it emphasized the dangers of fumigation; by drawing attention to the risks, it sought to reinforce its position with respect to its competitors.

As the companies grew, fumigation was used not just to fight pests in the fields, but became a common method for disinfecting households, commercial facilities, boats, and trains. The use of hydrogen cyanide in sanitary fumigation had previously been developed in the United States, where its success in fighting the bubonic plague in New Orleans in 1914 prompted its

\footnotetext{
74 “Una prueba de desinsectación por el procedimiento 'Grima', El Pueblo: diario republicano de Valencia, December 2, 1928.

75 "Del olivo," Guía del contribuyente rural: revista quincenal de materias económico-administrativas y judiciales, January 1, 1915, 22-24.

76 http://www.restauracionesfilmoteca.com/cine-espanyol-2/no-ficcio/cianogeratriz-grima/ (accessed April 5, 2019).

77 "Desde Vera," Crónica Meridional: diario liberal independiente y de intereses generales, January 26, 1912, 2.

78 "Valencia," Las Provincias: diario de Valencia, September 15, 1913, 2.

79 "Gacetillas," Diario de Valencia, January 31, 1914.
} 
application in hygiene control. In this same period, other seaports such as Havana started to apply these treatments in a more systematic way. ${ }^{80}$

The use of hydrogen cyanide in the Valencian seaport did not become common practice until the 1920s. The firms mentioned above, as well as local medical experts, were responsible for its implementation. Valencia gradually became an important centre of innovation in sanitary fumigation..$^{81}$

Overall, the private and public projects were a great success, thanks to the effectiveness of the treatment, the advertising campaigns, and even to the obligatory nature of the treatment in response to the pest law of $1908 .^{82}$ In the fifth edition of their fumigation manual, the engineers of the Burjassot Plant Pathology Station stated that "debido al desarrollo de esta industria en Valencia, puede considerarse a España como la primera nación de Europa en el tratamiento de plagas por este procedimiento" [due to the development of this industry in Valencia, Spain can be considered the leading nation in Europe for the control of pests through this procedure]. ${ }^{83}$

\section{Accidents and the press}

Cyanide fumigation was covered quite widely in the media, often in the form of reports of fatal accidents. In a search of the Virtual Library of Spanish Historical Newspapers, I identified as many as 30 cases of intoxication (in Spain as a whole, but mainly in the Valencian Country), reported in articles in a period between 1923 and $1933 .{ }^{84}$ Before and after this tenyear period these accidents were not covered to the same extent, though it is impossible to be sure whether this was due to a lower rate of occurrence or to a fall in interest on the part of the media. In the concluding remarks we shall come back to this difficulty of estimating the total number of accidents.

The intoxications were caused by fumigations in domestic or urban settings, orange fields, or ships in the port. There were also a number of cases of intoxication due to the growing presence of hydrogen cyanide in society as a whole: for example, due to the accidental consumption of

\footnotetext{
${ }^{80}$ Cebrián Gimeno, Manual de la desinfección.

${ }^{81}$ These events constitute the second stage in the development of cyanide fumigation in the Valencian Country and will be analysed further in another paper, now in preparation.

82 "La defensa de los naranjales," Diario de Córdova, July 19, 1912.

${ }^{83}$ Gómez Clemente and Regueral Bailly, Estación de Patología Vegetal de Levante. Instrucciones, 8.

${ }^{84}$ One feature of the reports compiled is the predominance of cases in Valencia. Although Valencian newspapers are underrepresented in the Virtual Library, more than half the cases covered in the press took place in the Valencia region; a fact that reinforces the previous argument on the special relevance of cyanide fumigation in this area.
} 
liquid hydrogen cyanide, mishaps while transporting barrels containing the substance, or the accidental consumption of almonds destined for the production of cyanide. The intoxications mainly took place in the local population but there was at least one case involving a foreign engineer: the American Paul Arriseon Karrik died while testing a new method for cyanide fumigation in the town of Sagunt, near Valencia. ${ }^{85}$

The growing presence of cyanide in the society probably encouraged some people to use it with criminal intent. Studies on the history of criminal poisoning have rarely focused on this substance; arguably, the easy detection of cyanide and hydrogen cyanide meant that they were rarely used as poisons, although some cases were occasionally reported. ${ }^{86}$ There was at least one report in the Spanish press from the period of a case of criminal poisoning using hydrogen cyanide, in Valencia, ${ }^{87}$ but the number of these cases was never as great as that of accidental intoxication.

Taking a broader geographical perspective, hydrogen cyanide was more extensively used in suicides or in murders in which there was no attempt to conceal the crime (as in the killing of prisoners in Nazi concentration camps or in US jails). ${ }^{88}$ The impact that these uses of hydrogen cyanide had on its regulation is still to be explored. ${ }^{89}$ In Valencia, none of these connections appear to have been relevant; the reports consulted do not show any clear relation and neither the gas chamber nor the use of hydrogen cyanide in chemical warfare seem to have had any relevance in the local context. As for its use in war, it had many detractors - not only among those who opposed war in general or chemical warfare in particular, but also among those who had no such qualms but complained about its lack of efficiency. ${ }^{90}$ And in Valencia, this inefficiency was mentioned in the contemporary monograph on chemical warfare written by

85 "Valencia," Las Provincias: diario de Valencia, September 16, 1924: 8.

${ }^{86}$ Albert Vingut, El ácido cianhidrico a través de la historia (Barcelona: Seminari Pere Mata, 1999).

87 "Una pena de muerte para un marido que envenenó a su esposa, ayudado por la suegra y la cuñada," El Pueblo: diario republicano de Valencia, June 8, 1926: 5.

${ }^{88}$ Scott Christianson, The Last Gasp: The Rise and Fall of the American Gas Chamber (Berkeley and Los Angeles: University of California Press, 2010).

${ }^{89}$ For DDT, the impact that its use in war had on its later use as a pesticide has been brilliantly analysed in Michelle Mart, Pesticides, a Love Story: America's Enduring Embrace of Dangerous Chemicals (Lawrence: University Press of Kansas, 2015). The relation between chemical war and pesticides has also been tackled extensively in Edmund Russell, War and nature: fighting humans and insects with chemicals from World War I to Silent Spring (Cambridge: Cambridge University Press, 2001).

90 Bretislav Friedrich, Dieter Hoffmann, Jürgen Renn, Florian Schmaltz and Martin Wolf, eds., One Hundred Years of Chemical Warfare: Research, Deployment, Consequences (Berlin: Springer, 2017). 
Robert Feo, a member of the short-lived Valencian Academy of Sciences - the Institut d'Estudis Valencians. ${ }^{91}$

Most of the cases of intoxication reported in the Spanish press of this period were related to accidents in urban fumigations either in households or on commercial premises. However, the superficial nature of the coverage of fatal intoxication cases in the agricultural setting suggests that the difference may be the consequence of a bias in the news covered by the media, rather than an accurate reflection of the frequency of these accidents in one and the other scenario. There might be two reasons for this bias: the prioritization of urban cases of intoxication over rural ones, and the consideration of intoxication as a public health hazard rather than as an issue of occupational health. ${ }^{22}$ Support for these hypotheses is found in the publications by contemporary authors like the occupational medicine specialist Jordana de Pozas, who condemned the press for its clear preference for events (in this case, intoxications) occurring in urban and industrial settings. He was also highly critical of the lack of regulation dealing with occupational health in agriculture. ${ }^{33}$ I shall come back to these points in my concluding remarks.

\section{Managing safety issues in agricultural institutions}

The safety of fumigation had clearly been a matter for concern ever since its introduction in the Valencian Country, as the writings of the local engineer Antonio Maylin bear witness. ${ }^{94}$ As mentioned above, in the early years of the century, Maylin warned against the expansion of this method because of its price as well as because of the risks it entailed.

Nevertheless, most of the numerous publications on cyanide fumigation during the first third of the century did not mention its high toxicity. In most cases, both in newspapers and in

\footnotetext{
${ }^{91}$ Roberto Feo Garcia, Agressius Quimics (València: Institut d'Estudis Valencians, 1937). In his book, Feo stated that the lack of success of hydrogen cyanide as a chemical weapon was due to the risks linked to its production, its fast disappearance in open-air conditions due to its lightness, and the difficulties in storing it in an active form.

92 The differences in the media coverage of fatal accidents in rural and urban contexts can be clearly deduced from the rich sample of news identified in my search of the Virtual Library of Spanish Historical Newspapers. For instance, the death of a farm worker in August 1929 received only a short note (Las Provincias: diario de Valencia, August 13, 1929), but the intoxication of a group of cooks while disinfecting a restaurant in 1928 was the subject of long and numerous articles (Las Provincias: diario de Valencia, November 30,1928), even though, unlike the farm worker, they survived.

${ }^{93}$ Jordana de Pozas, Accidentes del trabajo en la Agricultura (Madrid: Calpe, 1921).

${ }^{94}$ Maylin, Manual práctico.
} 
agricultural journals, the reports that did mention its danger went on to stress the need for further training of workers, rather than question the use of hydrogen cyanide as such. ${ }^{95}$

In the courses for fumigation foremen taught at the Burjassot Plant Pathology Station, safety measures were discussed and were addressed in one of the last sections of the manual that participants received on the first day of course. ${ }^{96}$ In this manual, future fumigators read about the different methods employed, the features of the tents used to cover the trees, the way each reagent had to be handled, and so on. Safety issues were occasionally considered, but normally (with the exception of the final section) the emphasis was placed on the safety of the tree rather than that of workers.

The safety measures to be implemented depended on the method of fumigation applied. In fumigating orange and olive trees in the Valencian Country, the generator was the main method used. ${ }^{97}$ Basically, this method comprised three different stages. First, the tree was covered with a special tent. Second, the volume of the tent covering the trees was calculated and, with this, the dose of reagents needed was also estimated. Finally, in the third stage, the worker would go into the tent, mix the reagents (usually water, potassium or sodium cyanide and sulphuric acid) and then quickly leave the tent, where the extremely toxic hydrogen cyanide would be generated. Many details were given on how each stage should be performed and many of these details were relevant for safety reasons.

The tent had to be well closed, have no holes, and remain dry in order to avoid unwanted exposure, and for matters of general safety. Many accidents occurred working with the tents. If not put in place carefully, the poles used to hold up the tent might accidentally pierce it; if the reagents were not mixed correctly, sulphuric acid might also damage the material. Some reagents included pollutants like sodium chloride, which could generate hydrochloric acid, an extremely corrosive substance. In case of perforation, the hydrogen cyanide could leak out of the tent and intoxicate the workers.

In relation to the handling of reagents, the most important issues were their purity (in order to avoid mishaps such as the accidental production of hydrochloric acid) and their dose. These variables had to be accurately established in order to produce hydrogen cyanide effectively, without unwanted residues. Again, any mistakes in this process could prove fatal.

\footnotetext{
${ }^{95}$ See for instance: "La campaña contra el 'poll roig'," Revista de Gandia, January 6, 1912, 1-2; Miguel Benlloch and José del Cañizo, "Los insectos de los graneros," Agricultura. Revista agropecuaria, October (1933): 679-83.

${ }^{96}$ The first edition of the manual, published in 1912, already included a section dealing with safety issues: Antonio Maylin, Instrucciones que deben observarse en los trabajos de fumigación con el ácido cianhidrico (Valencia: Tipografia Moderna, 1912).

${ }^{97}$ Gómez Clemente and Regueral Bailly, Estación de Patología Vegetal de Levante. Instrucciones.
} 
In mixing the reagents, while under the tent, the worker in charge had to avoid breathing and had to leave the tent as soon as possible. Failure to observe these instructions would be extremely serious, as the hydrogen cyanide was produced immediately after the mixing of the reagents and exposure even to low doses could end in tragedy. Workers did not wear masks or any special protection; once the gas was produced, the tent had to remain closed for a certain time before it could be opened. Failure to observe this stipulation was also an important source of accidents.

The fumigation foreman also had to bear in mind that the method could be used safely only in specific temperature and humidity conditions, since these reagents were extremely unstable. Interestingly, high humidity was a notable cause of problems, as it still is today in the orange producing areas of the Valencian Country. The wind was also an important issue: windy days were unsuitable for fumigation but extreme calm could also be dangerous, as the amounts of hydrogen cyanide that might leave the tent might not vanish quickly.

In fact, accidents were numerous and the fact that fumigation usually had to be carried out at night-time made them even more frequent. Nevertheless, these risks did not stop the rapid expansion of the practice.

As time passed, the methods used for cyanide fumigation in Valencia evolved, promoted as they were by both private and public initiatives. The new methods used different reagents such as calcium cyanide or liquid hydrogen cyanide. However, their introduction did not always lead to safer conditions. In fact, on several occasions the new methods were perceived as more dangerous; ${ }^{98}$ the use of liquid hydrogen cyanide, for instance, was responsible for a large number of fatal accidents, which were covered by the press. ${ }^{99}$

The manuals for cyanide fumigation bear witness to the wide range of factors affecting occupational safety. The measures proposed might be considered insufficient and their implementation often conflicted with other interests (it would be interesting to know whether it was actually possible to stop fumigation under unfavourable humidity or wind conditions, and whether the fact that fumigation was carried out at night increased the risk of error). But one could at least argue that the issue was explicitly addressed by people considered to be experts.

\footnotetext{
${ }^{98}$ Font de Mora, Nuevo Método de Fumigación.

99 Liquid hydrogen cyanide was especially dangerous, for a variety of reasons. One of the most important was to do with its storage and transportation. If the product had access to the atmosphere, noxious vapours were immediately produced and could intoxicate workers; in the traditional method, on the other hand, hydrogen cyanide vapours were only produced when the reagents were mixed in the fumigation.
} 
The courses were taught at agricultural stations, mainly at the Burjassot Plant Pathology Station. In both the outline of the courses and in the manuals, ${ }^{100}$ safety was mainly considered in relation to the use of these fumigations in the fields. In the manual by Gómez Clemente and Regueral Bailly, for instance, which ran to 90 pages, only one page and half were dedicated to the fumigation of granaries; the rest of the work was devoted to crop fumigation. However, the use of these fumigations in cities grew steadily during the 1920s and was the cause of numerous accidents. The press reports show that the same crews of fumigators working in the fields were usually in charge of urban fumigations, and arguably they were less well trained for this task.

\section{Managing safety issues through legislation}

The training of fumigation foremen was important in order to introduce safety measures in the use of hydrogen cyanide in crop fumigation, and in a very indirect way, in sanitary fumigation as well. However, the first safety regulations for the use of cyanide fumigation were only passed in the 1930s. Previous regulations, mainly concerning sanitary fumigation, had introduced measures that could avoid accidents but the first explicit attempts to regulate safety were made in response to the passing of an Order on 2 June 1933. ${ }^{101}$ The potential hazards of cyanide fumigation had already been verified in a number of acute intoxications, and several of these cases raised calls for further controls. For instance, in Valencia in 1926, after a professional fumigator died while working in the disinfestation of a bar, the Civil Governor responded by publishing an announcement ${ }^{102}$ establishing that anyone found to act imprudently when fumigating would be sanctioned. However, at this point no further regulations were introduced.

New cases of intoxication while fumigating with hydrogen cyanide were recorded and in 1933 the abovementioned order was passed. The order imposed the regulation of sanitary operations with hydrogen cyanide due to the repeated cases of intoxication, but no reference was made to intoxications of farmworkers in the fields who were using the same kind of fumigations (and, in fact, much more often). Although the cases of these latter intoxications were covered in the press, and although the publications of engineers mentioned the numerous serious accidents in the use of these fumigations, the 1933 order made no reference to them; it sanctioned sanitary fumigation in ports and the rail network under the strict supervision of the health authorities (and in other places as well, in exceptional cases in which the health authorities approved it).

In the following months the production of barrels of liquid hydrogen cyanide was regulated by the orders passed on 3 October 1933 and 30 January $1934 .{ }^{103}$ This method was being used by

\footnotetext{
${ }^{100}$ Gómez Clemente and Regueral Bailly, Estación de Patología Vegetal de Levante. Instrucciones.

101 Spanish Order of 2 June 1933.

102 “En el gobierno civil," La correspondencia de Valencia: diario de noticias, June 26, 1926, 1.

103 Spanish Order of 3 October 1933 and Spanish Order of 30 January 1934.
} 
Fumigadores Químicos S.A., and the company campaigned to modify the regulation in its own interest. However, the regulation was generally regarded as necessary, since a number of the cases of intoxication covered by the press were caused by accidents with the use of these barrels.

As far as we know, the regulation of the use of cyanide fumigation in agriculture was limited to the requirement of a licence for the foreman of the crew. From 1942 onwards, various products for cyanide fumigation were registered in the new official list for authorized pesticides. In the 1960s and 1970s the method was gradually eliminated from pest control as a consequence of the introduction of alternative methods which were then considered to be more effective or safer. However, hydrogen cyanide would not be banned, as it would be the case with DDT and many others.

\section{Final remarks}

The study of the introduction of cyanide fumigation in the Valencian Country constitutes an excellent opportunity to analyse the complexity of innovation processes in pest control. In this paper I have identified a number of historical actors whose efforts allowed the active appropriation of this method of pest control, which was first developed in California. In this process, engineers were not limited to a passive reception of a black-boxed methodology; doses were redefined, new and different pests were treated, the materials and instruments used in fumigations were redesigned, and new methods of fumigation were tested.

The engineers were not alone in this process of appropriation. Politicians and producers also played a crucial role. In Valencia, the Conde de Montornés, in particular, contributed in multiple ways to help introduce cyanide fumigation; indeed, the failure to implement these fumigations in the citrus fields of Sóller in Mallorca in 1905 when they were first proposed in order to fight red scale pests may have been due to the absence of a similarly dedicated and committed instigator.

Industry also played a very important part in developing new methods, in advertising fumigations in close connection with the media, and in determining legal regulations. I have highlighted its lobbying activity in referring to the campaign of the firm Fumigadores Químicos S.A. to transform the regulations of 1933 or to the role of the company Casa Grima in criticizing the practices of competing companies. I have also stressed the important role of the media in raising the profile of this fumigation methodology. As stated, the Valencian firms Casa Grima and J. Berdín y Ca invited journalists to see the potential of these fumigations first hand, and their activities appeared frequently in the press in the form of both reports and advertisements. When accidents might negatively affect the firms' growing reputation, these 
firms used their contacts with the media to clean up their image, as we saw in the case of the intoxication of the cooks in 1928.

Hydrogen cyanide was, and is, recognized as highly toxic. However, most of the numerous articles on cyanide fumigation played down this toxicity; risks were ignored or even dismissed. On specific occasions, for instance when Casa Grima challenged its competitors or when engineers publicized their courses, the risks were highlighted as a way to promote the firm or to stress the need to obtain the licence required. But the risks were never presented as something that might invalidate this methodology: the problem most commonly emphasized was its cost.

This lack of concern with risk in most of the publications is quite astonishing, as an exposure of a few seconds to hydrogen cyanide would be fatal. Indeed, this danger became public knowledge when accidents started to be covered by the press. This paper has assessed the poison in its different contexts in an attempt to determine whether this lack of concern was generalized; it has shown that, in this specific setting, the fact that it might adulterate food or be used as a criminal poison was not paid any special attention, and its threat as an environmental contaminant was totally ignored. Thus, the divide most clearly highlighted in my analysis is the one between occupational and public health hazards, which was further reinforced by a rural/urban divide. Although both hazards existed in both contexts, the public health risk was clearly more present in urban areas, and the occupational risk in agriculture was of barely any interest to the authorities.

The regulation of risk in crop fumigations (carried out mainly in the rural context) and sanitary fumigations (carried out mainly in towns and cities) took very different forms. In the countryside, the emphasis was placed on the recommendations taught on the courses of the Burjassot Plant Pathology Station, while sanitary fumigation, which would be implemented several years later, was regulated more strictly through specific rules. Indeed, the first rules regulating safety in cyanide fumigation, such as that of June 1933, referred only to sanitary fumigation.

This difference in regulation was due to a number of factors; the poor regulation of occupational health, the priority given to urban rather than rural hazards, and the possible differences in the outcomes of a risk/reward analysis for rural and urban applications. In any case, the fact that intoxications did not conform exactly to the definition of "accident" included in the Work Accident Act of 1900, and the fact that the law was not made applicable to agriculture until $1931,{ }^{104}$ both go a long way to explaining the invisibility of the risk. In this case, as stated in the works by Olga Kuchinskaya, Kevin C. Elliot and others, the passing of a new standard of regulation on work accidents may have contributed to the long-term concealment of the

${ }^{104}$ Decree of 12 June 1931. 
risk associated with cyanide fumigations. As the new standard excluded accidents in cyanide fumigation from any type of sanction or compensation, and as they were not considered to be occupational accidents, they were not the object of any statistical study. With no data and no specific case law to cite as precedent, the status of cyanide fumigation as an occupational hazard was easily rendered invisible. In contrast, the impact of fumigation on a third party - the general public - would be regulated in a variety of ways. These accidents in sanitary fumigation became more frequent over the years and, as they were not subject to the invisibilizing standards mentioned above, the legislators were forced to react. 